\title{
Official recognition of 2015 Global Geoparks applications: geological section evaluation
}

\author{
Marko Komac*, Roland Oberhaensli**, Patrick Mc Keever*** \\ *IUGS IUGS Vice-President \& liaison with GGN; \\ **IUGS President; \\ ***UNESCO, Chief of Section, Earth Sciences and Geohazard Risk Reduction
}

A Global Geopark is a unified area with geological heritage of international significancewith a strong management structure and sustainable economic development strategy already in place. Global Geoparks use the local and regional geological heritage with its strong relation to the technical and cultural heritage in the area to promote awareness of key issues facing society; to educate visitors and local communities; and to link these local and regionalpeculiarities to the broader aspects of the area's natural and cultural environment in the context of the dynamic planet we all live on.

Global Geoparks promote awareness of geological hazards, help prepare disaster mitigation strategies among local communities, educate on current climate change, promote best practise approach to utilising renewable energy and employing the best standards of "green tourism", inform about the sustainable use and need for natural resources, whether they are mined, quarried or harnessed from the surrounding environment, promote respect for the environment and the integrity of the landscape.

The Global Geoparks Network (GGN), supported by UNESCO, provides a global platform of active cooperation between experts and practitioners in geological heritage. Under the auspicesof UNESCO and through regional network partners, significant national geological sites gain worldwide recognition and visibility through tourism as well as best practices within the scientific and education community. Within a designated Global Geopark area, models of best practice are developed, setting high quality standards in all aspects of their operation.The GGN continues to expand each year, in May 2015 comprising 111 Global Geoparks in 34 countries from five continents.

The International Union of Geological Sciences (IUGS) is a partner with UNESCO and the GGN and assists in finding geoscientists - volunteerexperts in the fieldsrelevant to the aspiring Global Geopark applications - who are willing to evaluate the geological sections of each new Global Geopark application for their international significance. Given the fact that unique geological settings and their globally recognised importance are the foundation on which a Global Geopark is first established the evaluation of the geological section of a Global Geopark application follows high quality standards of and is of quintessential importance, a critical part of the Global Geopark evaluation process, and helps maintain the high global standards of the Global Geoparks Network.

In 2014, 17 new applications were submitted to UNESCO and these were evaluated in the first half of 2015. The 2015 aspiring Geoparks were (in alphabetic order):

Beaujolais (France), Belogradchik (Bolgaria), Celestienne, Lesse and Lomme(Belgium), Dunhuang (PR China), Golden Geopark of Lapland (Finland), Grevena Tethys (Greece), Imbabura (Ecuador), Izu Peninsula (Japan), Lochaber (Scotland), Mons (Belgium), Mount Apoi (Japan), Pollino (Italy), Shouf Jezzine (Lebanon), Sitia (Greece), Toba (Indonesia), Troodos (Cyprus), Zhijindong (PR China).

The evaluators for these 17 aspiring Geoparks were (in alphabetic order):

Michel BAKALOWICZ, S.K. BHUSHAN, Attilio BORIANI, Robert BUTLER, Jose-Pedro CALVO, Pedro CASTINERAS GARCIA, Patrick DE WEVER, Yildirim DILEK, Steve DRURY, Franz Wolfgang EDER, John HUGHES, Mike KATZ, Christian KOEBERL, Frédéric LACOMBAT, Richard LANGFORD, Randy MILLER, Greg MOORE, Damian NANCE, Adriana NIZ, Yujiro OGAWA, Nazire ÖZGEN ERDEM, Annie RASSIOS, Corina RISSO, Matti SAARNISTO, Veli-Pekka SALONEN, Harold STOWELL, Michiel VAN DER MEULEN, Benjamin VAN WYK DE VRIES, Guido VENTURA, Pierre VERPAELST, Nadja ZUPAN HAJNA and those other geoscientists that helped in the process, but choose to remain anonymous.

IUGS, UNESCO and the Global Geoparks Network would like extend their sincere gratitude to each of the evaluators for the excellent job and the time they dedicated to evaluatethe 2015 aspiring Global Geoparks. With their valuable contribution it is assured that the concept of the Global Geopark is built on expert geoscience knowledge of the geological heritage of global importance. Thank you all for helping to preserve the global geoheritage! 